\title{
反射式光電法を用いた血管位置検出法の開発 \\ Development of An Arterial Detective Method by Using Reflection-type Photoplethysmograpy
}

\author{
○下村 翔大 ${ }^{1}$ (山大工),大田 慎一郎 ${ }^{2}$ (山大院),末永 弘美 ${ }^{2}$ (山大院) \\ 正 安田 利貴 ${ }^{2}$ (山大院),斉藤 俊 $^{2}$ (山大院)
}

\author{
1. 山口大学 工学部 機械工学科, 2. 山口大学 大学院 医学系研究科 \\ OShota SHIMOMURA ${ }^{1}$,Shinichiro OTA ${ }^{2}$, Hiromi SUENAGA ${ }^{2}$ \\ Toshitaka YASUDA², Takashi SAITO ${ }^{2}$ \\ 1.Dept.of Mechanical Engineering, Facutly of Engineering, Yamaguchi University, \\ 2.Graduate School of Medicine, Yamaguchi University
}

\begin{abstract}
1. 緒言 我々は, これまで光電脈波波形から, 血管硬度を非侵 襲的に推定する研究を行ってきている. 1)一般的に, 脈波波形を 精度良く計測するには, 計測対象となる血管とセンサの位置関係 を常に一定に保つ必要がある. そこで, 本研究では, 光センサ (光電脈波法)を用いた動脈位置検出システムの構築を図り, 圧 カセンサ(トノメトリ法)を用いた脈波形測定装固の簡素化を目指 す.
\end{abstract}

光センサを用いた血管位置検出に際して, 血管およびその周 辺組織による散乱光強度への影響が不明である. よって, 本論文 の目的は, 異なる波長の光源を有する光センサを用いた動脈の 脈波形測定結果を, 生体を模擬した光伝播解析の計算結果, 超 音波による脈波形と比較, 榆討し, 受発光部位置を変化させた場 合に拈ける異なる波長の散乱光強度変化を明らかにすることであ る.

2. 脈波測定実験および光伝播解析 本実験では, 一般成人男 性の右手首撓骨動脈を対象とし, 実測および光伝播解析を行っ た. 脈波測定装置は反射型光センサ(YU-01, オプトテクノ), 発光 および受光用光ファイバ $(\phi=0.98 \mathrm{~mm})$, 光ファイバホルダ(受発光 間隔 $\mathrm{SD}=2 \mathrm{~mm}$ )および XY 軸リニアテーブルからなる. 図 1 に示す ように, 動脈が発光部の真下にくる位置 IP(Incidence Position $)=0[\mathrm{~mm}]$ を中とし, 皮膚表面にて受発光部を左右に士 $4[\mathrm{~mm}]$ まで $1[\mathrm{~mm}]$ 間隔で水平に移動させた, 計 9 点での測定を行 った. 発光部 LED 波長は, 生体組織の光特性を検討するために, 530,650,810[nm]とした.

図 2 に示すモデルより, 定常状態とした光拡散方程式用いて, 二次元光伝播解析を行った. 計算領域は $16[\mathrm{~mm}] \times 16[\mathrm{~mm}]$, グリ

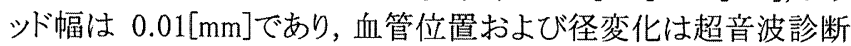
装置(Prosound SSD6500SV,アロカ)による実測より, 動脈の中心を 深さ方向 $\mathrm{x}=5.31[\mathrm{~mm}]$, 水平方向 $\mathrm{y}$ の中心 $\mathrm{y}=8[\mathrm{~mm}]$ に位置させ, 撓骨動脈の径変化の最大值 $\mathrm{d}=2.46[\mathrm{~mm}]$ と最小值 $\mathrm{d}=2.38[\mathrm{~mm}]$ の 2 通りで解析を行った。

3. 結果および考察 図 3(a)に, 血管が受発光部の中心に位置 するとき(IP=-1[mm])の実測の脈波形, また, 図 3(b)に動脈の正確 な脈波形を示すものとして, 超音波による径変化のグラフを示寸. 図 4 に示すグラフは, それぞれの波長における, 受発光部位置を 変化させたときの脈波の振幅を表している. 波長 $810[\mathrm{~nm}]$ の脈波 形において, IP=-3,0[mm]の位置で振幅のピークが表れている. 一方, 図 3(a)より波長 530[nm]の波形では, 超音波による径変化 の波形との決定係数 $\mathrm{R}^{2}$ を求めたとさ, 上下反転させたもので $\mathrm{R}^{2}=0.8912$, 反転させていないもので $\mathrm{R}^{2}=0.1353$ と上下反転してい ると考えられる波形が得られているのに対し, $\mathrm{IP}=-3[\mathrm{~mm}]$ での波形 では上下反転させたもので $\mathrm{R}^{2}=0.2468$, 反転させていないもので $\mathrm{R}^{2}=0.4118$ であり, どちらとも言えない波形となっている. また, 図 5 は, 光伝播解析により, 血管径 $\mathrm{d}=2.38,2.46[\mathrm{~mm}]$ における散乱光 強度の差をとったものであるが, 波長 $530[\mathrm{~nm}]$ の波形が, 実測結 果と同じく反転していることから, それぞれの波長による血管での 散乱係数, 吸収係数の違いから, 径变化に対する散乱光強度の 変化が逆転したものと考えられる.これらの結果より,この 2 波長

の測定による, 脈波の振幅, 反転現象の有無から動脈位置が推 定可能であると考えられる. しかし, 波長 $810[\mathrm{~nm}]$, 受発光部位置 $\mathrm{IP}=-3[\mathrm{~mm}]$ においての脈波形で振幅のピークが得られた理由に ついては不明である. 得られた原因としては, 同じ受発光位置 $\mathrm{IP}=-3[\mathrm{~mm}]$ において, 波長 $530[\mathrm{~nm}]$ の脈波形に反転現象が起こつ ていなかったことから, 毛細血管の存在などが考えられる. 今後, 超音波などによる測定から動脈周辺の詳細な組織の分布を明ら かにし，それを元にした光伝播解析からこの現象を明らかにして W.

4. 結言 脈波測定実験において, 発光部の真下に血管が位置 するとき, 波長 $810[\mathrm{~nm}]$ の脈波形に振幅のピークが表れ, 受発光 部の中心に血管が位娄するとき, 波長 $530[\mathrm{~nm}]$ の脈波形に反転 現象が起こった。

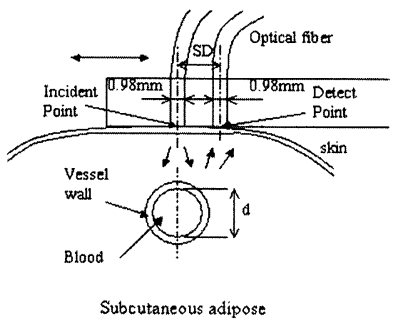

Fig. 1 The Experimental Set-up

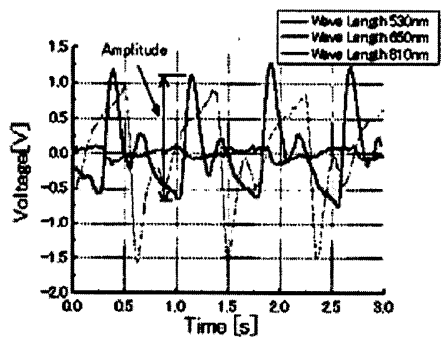

(a) Photoplethysmograpy

Fig.3 Time Course of Pulse Wave

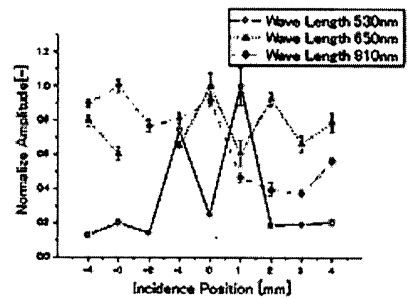

Fig.4 Effect of Incidence Light Wavelengths on ReflectedLight Intensity

参考文献

1) 大田慎一郎, 安田利貴, 齐藤俊: 動脈の力学指標の提案, 日本機械学会論文集(掲載決定), 2008

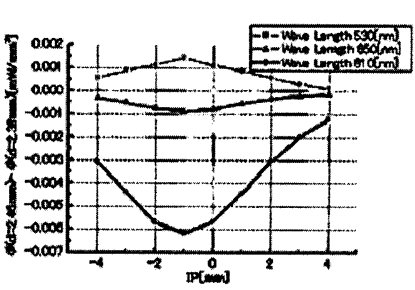

Fig. 5 Analysis Result of Reflected Light Intensity

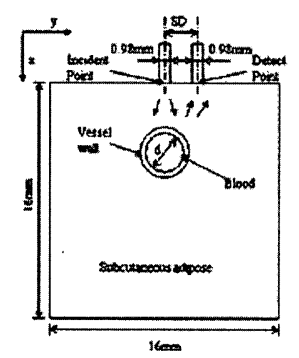

Fig.2 Analysis Model

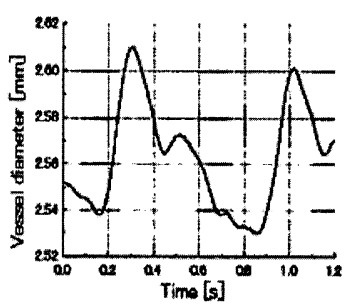

(b) Ultrasonic Pulse Wave 